\title{
The use of Learning Management System on University Students' Vocabulary Mastery
}

\author{
Ifit Novitasari ${ }^{1}$, Eko Aprianto ${ }^{2}$, Dwi Fita Heriyawati ${ }^{3}$ \\ 1,3) Universitas Kanjuruhan Malang, Jl. S. Supriadi No.48, Kota Malang, Indonesia \\ 2) STIKI Malang, Jl. Tidar Selatan No.100, Kota Malang, Indonesia \\ e-mail: ${ }^{1)}$ vita@unikama.ac.id; ${ }^{2)}$ ekoaprianto@stiki.ac.id; ${ }^{3)}$ dwifita@unikama.ac.id
}

\begin{abstract}
The development of learning media that is interesting and relevant to the education system in Indonesia, although the ability of learners is a barrier today. Various development efforts are always done to complement the process of material oblivion that has been given. Learning methods and learning media are two things that cannot be ignored. Having English skills will add value in the context of human resources. But in an academic environment, English is a foreign language that needs to be mastered not only in communication but also in terms of technology and science. The increasingly rapid technological development takes part in the learning development system. Many learning media are used to improve the ability of information or science. Furthermore, this study uses learning management system (LMS) as one of the technology media to improve students' vocabulary. The study focuses on the effort to improve vocabulary mastery by using learning management system. The subjects of this study were the second semester students from informatics department, Universitas Kanjuruhan Malang. The results of this study show that the students are easier to understand the vocabulary used in technology informatics fields. It can be seen that the results of their average of final score is 85.00 improved higher than the previous score, before the use of LMS in the teaching vocabulary, the score is 65.00. It is expected that the result of this study can be one of the alternative way to help students understand the vocabulary easily.
\end{abstract}

Keywords: LMS; vocabulary mastery; learning media

\section{Introduction}

Language has an important role in the human communication. In relation to the important of communication in human life, briefly the nature of human language is as an arbitrary system of sound symbols used by members of the community to communicate and recognize one another. English is the language most often used by foreign speakers throughout the world. When people with various languages come together, they generally use English to communicate with each other. Therefore, English is a foreign language which is an absolute requirement to be studied in the education world in Indonesia.

The basic core to acquiring the language is the learners should understand the vocabulary as part of the important of language. According to Jack (2002:225) vocabulary is a core component of language proficiency and provides much of the basis for how well learners speak, listen, read, and write. Based on the purpose of vocabulary drill stated in the definition of term, the researchers define vocabulary as stocks of words in a language that can support the learners lo learn the skill of the language (Heriyawati, 2010).

However, the English learning system implemented in Indonesia is not maximal. Teaching English so far, especially for non-English students, only refers to textbooks, 
and emphasis only on reading mastery. English learning that only prioritizes reading comprehension makes students less aware of the use of English properly, sometimes they also experience difficulties in vocabulary mastery. When learners have limited vocabulary, the ability to understand and use a language in communication both verbally and in writing will also be limited. In this condition we can help the students to connecting between reading text and vocabulary mastery. It is in line with Heriyawati, Saukah, \& Widiati (2018) who stated that knowledge (e.g. semantic and syntactic) help learners to predict words from sentence cues or to predict meaning; they have enough linguistic knowledge and background knowledge to read and understand the text without considerable difficulty.

Recognizing the lack of learning media and the appropriate learning methods in the teaching and learning process of English, especially for students majoring in Information Technology, English teachers are expected to be aware of participating in teaching English language education to students at the beginner level by providing media and methods. The teachers should facilitate learners with various media and facilities. The teachers must be familiar with the development of technology. The learners are more familiar with the technology, so in order to make the teaching learning process more interesting, the teachers should combine the technology and the materials given in the classroom, especially for vocabulary mastery (Heriyawati \& Aprianto, 2018). Moreover, in the teaching and learning process the teachers should also consider the interesting and easy way to absorb and applied the proper method for learning as a form of developing English language skills.

The development of materials and teaching media in the education system in Indonesia become one of the global problems and requires to renewal. Materials and teaching media that always developing and interesting in teaching English are challenges to developed together. Media that is relevant for the current teaching and learning system also has its own impact for the achievement of the students in understanding English vocabulary.

Information technology that is developing rapidly is able to bring renewal in the teaching and learning process in the education system in Indonesia. Some learning processes have begun to use appropriate technology applications to achieve maximum understanding in the classroom. Learning management system (LMS) is one of the right application use in teaching English. The development of teaching materials, training, as well as interesting activity activities with LMS are expected to be able to improve the students' of vocabulary mastery. Based on the above description, the researchers intend to examine the problems in depth by connecting vocabulary subjects with technology. The vocabulary test will also provide online, so, the learners will do the test online. In this case the researchers expect that the use of technology in the teaching and learning process will be more effective. The purpose of study is to implemented technology in the teaching and learning process, especially for vocabulary in English for informatics technology course.

\section{Methods}

In this study, the research design used was descriptive qualitative research. The researchers used learning management system (LMS) for teaching English for informatics technology department. In the end of the session the researchers asked the 
students to do the test through the online version. The tests were administered in 90 minute through internet. The results of the students' tests were recorded directly in the end of the test. The researchers also distributed questionnaire and interviewed the students related to the use of learning management system (LMS) in the teaching and learning process. The participants of this research were 45 students from the second semester students of Informatics department who take English for informatics technology course. This study was conducted from June to August 2018.

The results of the students' test were analyzed statistically; the researcher calculated the students' average score in order to know their abilities to acquiring English vocabulary for informatics technology. To get the further opinion from the students related to the implementation online reading test, the researcher conducted interview section with the students. The interview was conducted after the students finished their task. All the data got from the students were analyzed in order to know whether the implementation of online reading test were sufficient or not.

\section{Findings and Discussion}

\section{Findings}

The findings of this research are based on the result of the implementation of teaching learning process which is conducted by using learning management system (LMS). The study is implemented during 4 meetings. The result of interview with the students is related to the process of teaching and learning. The interview is intended to obtain the difficulties of studying vocabulary in English for IT recently. To support the result of interview, the researchers also conducts the direct observation inside the class. Furthermore, the researchers also do observation and distribute the questionnaire related to the process of evaluation to measure the students' understanding of vocabulary. At the beginning, the researchers have modified the teaching materials especially for English for IT which is appropriate for the student ability and compile the material for the 2 nd semester students. Then, the researchers input the materials into the learning management system (LMS). Before the materials being selected, the researchers validate the vocabulary materials with the expert from the senior lecturer of English department, Universitas Kanjuruhan Malang. The fix vocabulary materials are input into learning management system. Afterward, the researchers implement the teaching vocabulary through online learning by using LMS to know the students' improvement.

In this study, the observation obtained generally activities teaching learning of implementing online media is not recorded in detail. At the beginning, the students find some difficulties in using online media as a learning tool and how to understand the material and instruction in the online media. The researchers provide a dummy materials to ease the student acquiring the teaching materials. The next meeting, the students are invited to present the result of their study related to the difficulties in understanding the materials provided online. In the implementation of LMS, it shows that the interaction among students and researchers also conducted online. The teaching learning process in the classroom only provide some instructions and explanations from the lecturer. The results of this study are also supported by the result of questionnaire. The interaction

Linguista Vol. 2, No. 2, Desember 2018: $72-79$ 
happens among the students and researchers at the beginning of meeting and at the end of meeting while the researchers provides an assignment. The results of questionnaire show that $75 \%$ from 46 students argue that they agree with the use of online media in the teaching and learning process. The last meeting, the researchers find different phenomenon in implementing online media. The students and researchers actively involved in the classroom interaction in term of providing an assignment, sharing information and direct interaction in order to solve and discuss some problem in teaching learning process. In the last session, the researchers also present the first post-test for 60 minutes and conduct informal interview to gain the students opinion related to the difficulties in the teaching and learning process. The results show that the students extremely face difficulties to understanding the material.

The researchers find some problematic factors of implementing online media in teaching vocabulary. For instance, the students are not able to comprehend online media completely, it might of the less sharing and discussion among the students. The students do not focus on learning, are less motivated, passive in the process of teaching and learning and felt uncomfortable with online media. Others, as the supporting tool such as laptop and internet connection are also the problematic factor while the students only using Android mobile phone and depending on the Wi-Fi. The final results of the study show that the score of students' post-test was 8.5 indicated that the students are able to understand the materials completely.

The questionnaire showed that some phenomenon appears during implementing online media. First, a noise was the students' difficulties in using learning management system during vocabulary teaching learning process. It makes the researchers unable to control the condition. They are talking each other and confuse with the use of LMS while the researchers explain the media. Second, the students feel need more time to understand the material provided online. They need more time to accomplish the assignment given by the researchers. Otherwise, at the beginning the students also find difficulties to use this media and waste the time during the learning. Third, the students get difficulties in term of lack the English skill. It is quite difficult for them to comprehend the vocabulary materials. They need more additional tool to help them such as dictionary. The ability of using technology and internet connection are also one of the difficulty for them.

The researchers also collected the response from the students. The positive response shows that $22 \%$ students are interested in this method, $75 \%$ students said the use of LMS extremely appropriate for vocabulary learning, $42 \%$ students said this strategy was delighted, and $83.3 \%$ students agreed that this method was implemented in the future. Otherwise, the negative response also occurs where $20 \%$ students give their responses that the method was not interesting and not attractive, while the students only focus on the material given through online media.

\section{Discussion}

The finding of this study explain that the use of learning management system (LMS) especially for teaching vocabulary, make the students easier to understanding the meaning of the words. It shows that the use of learning management system makes the students easier to acquire the English materials, and it can be said 
that this media is more effective than the offline version. In the first time the students feel shock with the new method of learning, but then, they feel comfort in joining English course. They found the new experience in the teaching and learning process. In the implementation of the use of learning management system in the teaching learning process, the students found new experiences in learning English. The English for IT which is provided online or offline through the learning management system help the learners to learn with the new environment of the teaching and learning process.

Before the researchers implemented the teaching learning through online to the students, the researchers met the senior lecturer for validating purposes of materials. First, the experts, who experienced in the teaching and testing of English as Foreign language, were asked to select the English materials properly and to classify the materials based on some criteria provided by the researchers and based on the students need. Furthermore, the researchers selected the materials and decided the materials for the university students. The researchers conducted this way in order to decide the appropriate materials for the students. The result of the expert validation and was used as the materials in creating online materials for English for IT online.

From the results of the expert validation and the researchers selected materials, then, the researchers created the software as the materials for the teaching English for IT, especially vocabulary course for the university students. The vocabulary materials provided online in the computer with the assignment, media and instruction from the teachers. The learners get the benefits to learn through the use of information technology. They practice to learn online anytime and they do the exercises through the computer. The results of this study indicate that foreign language learning among students a foreign language can be significantly influenced by materials provided by the teachers based on the students need. On the other hand, the use of information technology appears to get the interaction among the students' in understanding the English vocabulary for IT.

Based on the finding of this study, the students also have different ideas, but in general they express positive perceptions. When the teacher-researcher was introducing learning management system, the students looks motivated to understand more not only the content but also the program. In this case, the researcher do not focus on the ability of the students in completing the task but how they operate the LMS program and understand the learning materials. The use of technology in the teaching learning process motivates the students to learn more since the process of teaching-learning becomes more interesting. Miyazoe and Anderson (2010) also revealed that the motivation of the students increases when they are treated using online learning. Padurean and Margan (2009) say that the use of online learning brings variety in classrooms and a pleasant way of learning. Domalewska (2014) also adds that ICT promotes the students in the learning process modifying the way learning takes place. The students look enthusiastic when being treated using online learning through LMS. They feel free in studying the materials anytime not only to discuss the contents of of the materials online but also to do the instruction of the teacher. It was very easy for them to express what they learn through media online, because they can access anytime through their gadgets.

The learning management system (LMS) is more developed to make the situation and the materials of learning more various. The materials of teaching English vocabulary

Linguista Vol. 2, No. 2, Desember 2018: $72-79$ 
are more suitable with the students' needs and more authentic. It is also based on the curriculum. The development of the materials and curriculum are based on the students' need, the situation, the students' environments, and the students' level of proficiency.

From the finding of the research, it can be explained that the implementation of online learning can improve the students' ability especially for English vocabulary mastery. This can be viewed from the result of the analysis of process and product implemented throughout the research. The vocabulary test is administrated by the researchers at the end of the study. The materials of the test are taken from the English text provided online through computer.

After the implementation online learning about 5 times, the researchers know that the students feel comfort with the online learning. The online English vocabulary materials really helps learners. For the first time the students feel worried with the teaching learning process, because they still unfamiliar with the LMS, but for the next session the students feel enjoy with the process of teaching and learning. They do it just like they play a game, so the students' stressful feeling in learning are decreased. Furthermore, in the implementation of online learning, the students and the lectures not only use technology for the pleasure but also for the academic purposes.

The use of teaching learning using LMS differs from traditional approaches to teaching English for IT. It can be suggested by the teacher to use the online media and materials through the computer as an alternative way to improve the teaching learning process because this strategy can make the students interested in writing, reading, and speaking. When the students practice all the components of the language skill together, it enables the students to memorize the information longer than the students only see it (Heriyawati \& Aprianto, 2018). By using learning management system (LMS), it saves the energy for the teachers in correcting and controlling the students' works, and by the end of the test the students get the results of the test directly. Then, the teachers have the summary of the students' scores and activities of learning. The information technology can give the chance for the students to discuss their difficulties in group, and they have the chance to use the technology as the media for the teaching and learning process. It also gives the students understanding about the vocabulary and the grammar use easily.

\section{Conclusion}

From the finding of this study, it can be seen that the implementation of learning management system in the teaching learning process of vocabulary really helps the students in understanding the meaning of the words especially in English for IT. It also provides new experiences for the students especially in vocabulary learning. The students feel free from the burden when they learn the materials, although they have to face their own computer, they do not feel worried about the assignment and the test. Their abilities to understanding the meaning of the words are improved significantly, because they have the model through the computer. Overall, the students' vocabulary mastery is improved as it can be seen from the result of the students test. The average score of the students' English test is 8.5, from 46 students in the English for IT course. It means that the students really enjoy and get the advantages in the implementation of online learning through learning management system. The teachers also get the benefits; the teachers get the results of the students score and their progress of learning directly without waiting too long in correcting the students' test. The teachers also can 
control the students' online activities. Furthermore, the online English materials for teaching learning activities for the students need to improve every time based on the students need and the students' level of proficiency. The researchers suggests other researchers to explore more about the implementation of online learning and online media by using special software in large scale research, using other various types of learning media, having material to be explored, and adequate time to employ.

\section{References}

Domalewska, D. 2014. Technology-Supported Classroom for Collaborative Learning: Blogging in the Foreign Language Classroom. International Journal of Education and Development using Information and Communication Technology (IJEDICT), 10 (4), 21-30.

Gebhard, Jerry G. 2011. Teaching English as a Foreign or Second Language. Michigan: University of Michigan Press.

Heriyawati, D.F. 2010. Teaching English Vocabulary through Song. Book chapter 1st Edition The Teaching of Language Skills and English Language Component. State University of Malang Press, Malang.

Heriyawati, D.F., \& Aprianto, E. 2018. The Implementation of Online Reading Test to The University Students. Jurnal IImiah and Edukasi, Volume 9, Nomer 1, Maret 2018, pp. 38-42.

Heriyawati, D. F., Saukah, A., Widiati, U. (2018). Working memory capacity, content

familiarity, and university EFL students' reading comprehension. Indonesian Journal of

Applied Linguistics, 8(1), 21-27. doi: 10.17509/ijal.v8i1.11458

Kamaruddin, S.A. 2012. Character Education and Students Social Behavior. Journal of Education and Learning. Vol. 6 (4), 223-230.

Miyazoe, T. \& Anderson, T. 2010. Learning Outcomes and Students' Perceptions of Online Writing: Simultaneous Implementation of a Forum, Blog, and Wiki in an EFL Blended Learning Setting. An International Journal of Educational Technology and Applied Linguistics, Vol. 38 (2).

Nunan, D. (2001). Second Language Acquisition. Carter, R. \& Nunan, D., (eds.). The Cambridge Guide to Teaching English to Speakers of Other Languages [C], pp 87-92. Cambridge: Cambridge University Press.

Padurean, A. \& Margan, M. 2009. Foreign Language Teaching Via ICT. Revista de Informatica Sociala. Vol. VII (12).

Linguista Vol. 2, No. 2, Desember 2018: 72 - 79 
Richard, Jacks. C \& Renandya, Willy A. 2002. Methodology in Language Teaching. Cambridge; Cambridge University, Press. 